\title{
KETERJANGKAUAN INFORMASI DALAM PELAYANAN PUBLIK
}

\author{
Firdaus ${ }^{1}$, Susi Lawati ${ }^{2}$ \\ 1) Staf Pengajar Magister Administrasi Publik Program Pascasarjana Universitas \\ Sjakhyakirti Palembang \\ 2) Staf pengajar Magister Administrasi Publik Program Pascasarjana \\ Universitas Sjakhyakirti Palembang \\ Email : firdausfakih62@gmail.com, uchi_fi2n@yahooo.com
}

\begin{abstract}
ABSTRAK
Rendahnya kualitas pelayanan publik di Indonesia sudah lama menjadi keluhan masyarakat. Hal ini ditandai dengan rumit dan mahalnya harga pelayanan, serta sulitnya untuk memperoleh akses terhadap pelayanan publik. Kondisi demikian tidak sejalan dengan upaya pemerintah untuk mewujudkan pelayanan prima kepada masyarakat. Dikeluarkannya UU No. 25 Tahun 2009 tentang Pelayanan Publik, merupakan langkah dan harapan besar akan terwujudnya pelayanan publik yang berkualitas. Di dalam UU No. 14 Tahun 2008 tentang keterbukaan informasi publik dikatakan bahwa informasi publik diartikan sebagai informasi yang dihasilkan, disimpan, dikelola dan atau dikirim/diterima oleh suatu badan publik yang berkaitan dengan penyelenggaraan Negara dan/atau penyelenggara dan penyelenggara badan publik lainnya yang sesuai dengan UU ini serta informasi lain yang berkaitan dengan kepentingan publik. Aksessibilitas informasi merupakan dimensi yang mempengaruhi pelayanan publik, hal ini didasari oleh pemikiran bahwa secara subtansial pengelolaan informasi publik saat ini telah mendapatkan perhatian serius dari berbagai kalangan, baik pemerintah maupun lembaga publik lainnya. Informasi publik merupakan hak dasar yang mesti dipenuhi oleh lembaga publik untuk disebarkan kepada masyarakat. Oleh karena itu dibutuhkan pengembangan sistem dan metode pelayanan informasi publik yang terpercaya dalam pelaksanaan pelayanan publik Ketersediaan informasi pelayanan yang selalu "up to date" dan transparan merupakan kebutuhan yang mutlak diperlukan berupa informasi mengenai data dan dokumen yang diperlukan secara lengkap dan mudah diakses oleh masyarakat terkait dengan jenis layanan yang dibutuhkan.
\end{abstract}

Kata Kunci: Aksessibilitas, informasi, dan pelayanan publik.

\section{PENDAHULUAN}

Penyelenggaraan pelayanan publik merupakan upaya negara untuk memenuhi kebutuhan dasar dan hakhak sipil setiap warga negara atas barang, jasa, dan pelayanan administrasi yang disediakan oleh penyelenggara pelayanan publik. Undang-undang Dasar (UUD) 1945 mengamanatkan kepada negara untuk memenuhi kebutuhan dasar setiap warga negara demi kesejahteraannya. Efektivitas suatu sistem pemerintahan sangat ditentukan oleh baik atau buruknya penyelenggaraan pelayanan publik.
Rendahnya kualitas pelayanan publik di Indonesia sudah lama menjadi keluhan masyarakat. Hal ini ditandai dengan rumit dan mahalnya harga pelayanan, serta sulitnya untuk memperoleh akses terhadap pelayanan publik. Kondisi demikian tidak sejalan dengan upaya pemerintah untuk mewujudkan pelayanan prima kepada masyarakat. Dikeluarkannya UU No. 25 Tahun 2009 tentang Pelayanan Publik, merupakan langkah dan harapan besar akan terwujudnya pelayanan publik yang berkualitas. Pelayanan yang berkualitas adalah pelayanan yang dapat memberikan kepuasan semua pihak, mulai dari penyelenggara 
pelayanan itu sendiri hingga kepada masyarakat yang dilayani. Substansi undang-undang tersebut telah mengarah kepada bentuk perwujudan kualitas pelayanan yang diinginkan oleh semua pihak (stakeholder). Namun demikian, yang sering terjadi permasalahan bukan pada regulasi tersebut, tetapi masalah terkadang muncul dari sisi implementasinya. Pelayanan publik menupakan salah satu agenda pembicaraan yang cukup hangat ditengah-tengah masyarakat. Signifikasi untuk mengkaji pelayanan publik akhir-akhir ini terkait dengan usaha-usaha untuk menciptakan clean government, demokrasitisasi, hak asasi manusia dan keadilan sosial. Paradigma mutahir dalam organisasi public menurut Denhardt dan Denhardt (2007:28-29) adalah paradigma New Public Service (NPS) sangat berbeda dengan paradigma Old Public Administration (OPA) yang menekankan peran pemerintah sebagai rowing, dan paradigma New Public Manajemen (NPM) pemerintah bertindak sebagai steering, sedangkan paradigma New Public Service (NPS) peran pemerintah sebagai serving. Asumsi terhadap motivasi pegawai dan administrator pada paradigma New Public Service (NPS) yaitu pelayanan publik dengan keinginan melayani masyarakat.

Sejalan dengan perkembangan paradigma tersebut, maka peningkatan kualitas pelayan publik merupakan tugas pemerintah untuk mewujudkan. Pelaksanaan pelayanan publik oleh aparatur pemerintah kepada masyarakat merupakan wujud dari fungsi aparatur Negara sebagai abdi Negara dan abdi masyarakat. Mengingat ruang lingkup pelayanan publik yang diberikan oleh aparatur pemerintah sangat luas dan kompleks, baik menunut bentuk, jenis dan sifatnya, maka upaya untuk menolak dasardasar proses pelayanan sungguh merupakan suatu hal yang sangat mendesak dalam rangka mengatasi kompleksitas dari pelayanan tersebut. Pelayanan publik yang diharapkan masyarakat saat ini, bukan sekedar untuk diperhatikan dan dilakukan pemerintah, tetapi sudah mengarah kepada tuntutan pelayanan yang berkualitas. Tuntutan itu seirama dengan semakin meningkatnya pengetahuan dan pemahaman masyarakat terhadap makna kehidupan bemegara yang dilandasi paham demokrasi (kedaulatan rakyat), sebagaimana diatur dan ditegaskan dalam UUD 1945. Masyarakat semakin sadar, bahwa mereka tidak hanya memiliki dan memikul tanggung jawab terhadap eksistensi negara, tetapi juga memiliki hak yang harus dipenuhi oleh negara (pemerintah) sebagai feed back atas pemenuhan tanggung jawab dan kewajiban terhadap negara, sesuai dengan ketentuan peraturan perundangundangan. Pelayanan publik, dikategorikan berkaitan dengan keputusan atau ketetapan pemerintah untuk melakukan suatu layanan yang dianggap membawa dampak positif baik bagi kehidupan masyarakatnya. Pelayanan publik kadang menunjuk pada konsep untuk menjelaskan pilihan tindakan layanan tertentu yang sangat khas atau spesifik, seperti kepada bidang tertentu seperti dalam sektor layanan fasilitas umum, transportasi, pendidikan, kesehatan, perumahan, atau kesejahteraan. Urusan yang menyangkut kelistrikan, air, jalan raya, sekolah, rumah sakit, perumahan rakyat, dan lembaga rehabilitasi sosial. Selain itu, layanan publik memiliki legalitas hukum.

Pelayanan publik merupakan penjelasan ringkas untuk menerangkan berbagai kegiatan layanan mulai dari pembuatan keputusan, implementasi dan evaluasinya. Telah banyak upaya untuk mendefinisikan layanan publik secara tegas dan jelas, namun tumpang tindih, ambigu, dan luas, akibat sempit dan minimnya penafsiran batasan layanan umum yang diidentikkan dengan layanan jasa. Beberapa pihak mengartikan layanan publik hanya sebatas layanan jasa resmi, seperti layanan yang diatur melalui keputusan perundangundangan. Sebagian lagi mengartikan layanan publik sebagai layanan yang memiliki pedoman, acuan, strategi dan kerangka tindakan khusus yang dipilih atau ditetapkan sebagai garis besar atau roadmap pemerintah dalam melakukan kegiatan pelayanan kepada masyarakat. Maka dalam penelitian ini, yang dimaksud dengan pelayanan publik adalah, segala maklumat/pernyataan layanan yang dikeluarkan pemerintah, baik itu termaktub dalam peraturan perundang-undangan/ peraturan pemerintah maupun dokumen kebijakan strategis 
pemerintah yang terkait dengan kepentingan dan tuntutan masyarakat.

Walaupun tuntutan peningkatan kualitas pelayanan dari masyarakat semakin deras, tetapi menurut Sinambela (2008:4) : Patut diduga, bahwa banyak birokrat yang tidak memahami secara pasti atau setidaknya tidak mengerti filosofi pelayanan yang akan diberikannya sehingga pelayanan publik yang diimpikan masyarakat jauh dari kenyataan yang mereka alami. Pelayanan publik yang diselenggarakan oleh pemerintah dipengaruhi oleh berbagai faktor, baik faktor-faktor yang ada dalam pihak pemerintah sebagai penyelenggara layanan, maupun faktor-faktor pada pihak masyarakat sebagai penerima layanan. Berikut akan dikemukakan pandangan para ahli mengenai faktor-faktor yang mempenganuhi kualitas pelayanan publik. Thoha (1995 : 181) mengemukakan 2 (dua) faktor penting yang mempengaruhi kualitas pelayanan publik yang diselenggarakan pemerintah, yaitu:

1) Faktor Individual menunjuk pada sumber daya manusia yang ada dalam organisasi. Semakin tinggi kemampuan sumber daya manusia dalam organisasi tentu semakin besar kemungkinan organisasi yang bersangkutan untuk menyelenggarakan pelayanan yang berkualitas.

2) Faktor Sistem yang digunakan untuk menunjuk pada mekanisme dan prosedur pelayanan yang digunakan. Dalam hal ini pada umumnya semakin rumit dan berbelitbelit prosedur mekanisme penyelenggaraan pelayanan publik (public service), justru semakin sulit mewujudkan pelayanan publik yang berkualitas. Sebaliknya, semakin sederhana dan transparan mekanisme prosedur yang digunakan, maka semakin besar kemungkinan untuk meningkatkan kualitas pelayanan publik.

Aksessibilitas informasi merupakan dimensi yang mempengaruhi pelayanan publik, hal ini didasari oleh pemikiran bahwa secara subtansial pengelolaan informasi public saat ini telah mendapatkan perhatian serius dari berbagai kalangan, baik pemerintah maupun lembaga public lainnya. Informasi publik merupakan hak dasar yang mesti dipenuhi oleh lembaga publik untuk disebarkan kepada masyarakat. Oleh karena itu dibutuhkan pengembangan sistem dan metode pelayanan informasi public yang terpercaya dalam pelaksanaan pelayanan publik Selanjutnya di dalam UU No. 14 Tahun 2008 tentang keterbukaan informasi publik dikatakan bahwa informasi public diartikan sebagai informasi yang dihasilkan, disimpan, dikelola dan atau dikirim/diterima oleh suatu badan publik yang berkaitan dengan penyelenggaraan Negara dan/atau penyelenggara dan penyelenggara badan public lainnya yang sesuai dengan UU ini serta informasi lain yang berkaitan dengan kepentingan public.

Ketersediaan informasi pelayanan yang selalu "up to date" dan tmsparan merupakan kebutuhan yang mutlak diperlukan. Pelayanan kepada masyarakat berupa informasi mengenai data dan dokumen yang diperlukan secara lengkap. Rosady Ruslan (2001 : 90) mengatakan: Fungsi sesungguhnya dari informasi adalah untuk mengurangi ketidak pastian dalam suatu sistem komunikasi disuatu lembaga atau organisasi. Informasi dewasa ini bukan lagi berupa untaian kata yang mengandung arti, tetapi sudah meliputi jasa, barang, proses, mulai dari sumbernya sampai pada hasil akhir Terkait dengan hal tersebut, untuk mengukur faktor aksessibilitas informasi dalam pelayanan public sebagai mana ukuran yang digunakan oleh PBB pada survey tahun 2008 yang dikutip oleh Martin Simaora 2010 (http:/4.bp.blogspot.com) dimana PBB melakukan survey e-Goverment terhadap 192 negara anggota PBB pada tahun 2008 dengan melakukan asesmen pada seluruh website kementerian disemua negara anggotanya terhadap keterjangkauan informasi meliputi indikator-indikator, 1) Keberadaan website, 2) keberadaan web portal, 3) Keberadaan Kepala website Nasional, 4) Keberadaan sebuah seksi e-Government, 5) Pengadaan berbagai sumber arsip informasi (perundangundangan,dokumen-dokumen, kebijakan, prioritas dan lain-lain),6) Berita dan berbagai "up date" kebijakan-kebijakan 
pemerintah,7) Akses keberbagai apilikasi :back office", 8) Keberadaan Chief Information Officer (CIO), 9) Informasi terkait tanggung jawab aparatur pemerintah terhadap layanan berbagai online, 10) Ketersediaan akun personal/profil yang bertujuan untuk memutahirkan dialog antara pemerintah dengan masyarakat, 11) ketersediaan informasi bagi masyarakat dalam menggunakan website Dalam tulisan ini, penulis hanya menggunakan 5 (lima ) indikator dari 11 (sebelas) indikator hasil survey PBB, hal ini karena disesuaikan dengan hal-hal yang terkait langsung dengan pelayanan yang dilakukan lembanga pemerintah kepada masyarakat. Adapun ke-5 (lima) indikator tersebut adalah; 1) Keberadaan wibesite, 2). Pengadaan berbagai arsip informasi pelayanan, 3) Berita terbaru tentangg pelayanan, 4) Akses ke berbagai aplikasi,5) Ketersediaan informasi bagi masyarakat dalammenggunakan website .

\section{PEMBAHASAN}

Keberadaan website Perananan website sebagai sarana komunikasi yang memuat segala informasi resmi dari suatu organisasi baik organisasi pemerintah maupun swasta. Organisasi pemerintah yang mempunyai tugas memberikan layanan publik, keberadaan website harus diyakini adalah sebuah situs informasi, dimana masyarakat yang ingin mendapatkan informasi yang mereka harapkan dapat di peroleh dari website.

Kepemilikan situs website bagi suatu organisasi pemerintah yang memberikan layanan publik merupakan suatu langkah dalam mewujudkan e-service pada pelayanan yang berkualitas. Fungsi website adalah sebagai media sosialisasi informasi proses dan syarat-syarat pelayanan yang dibutuhkan oleh masyarakat. Sosialisasi secara online yang dilakukan menupakan implementasi dari kebijakan pelayanan yang berbasis website. Terkait dengan pelayanan pelayanan publik, E-service memalui website merupakan upaya untuk memanfaatkan teknologi informasi dan komunikasi dimaksudkan untuk meningkatkan efesiensi, efektifitas, transparansi dan akuntabilitas penyelenggaraaan pelayanan.
Perkembangan teknologi informasi dan komunikasi menawarkan solusi untuk meningkatkan pelayanan yang berkualitas. Oleh karenanya keberadaan website pada instansi/lembaga pemerintah yang memberikan layanan kepada masyarakat harus dimanfaatkan secara maksimal dengan melakukan sosialisi kepada masyarakat agar dapat di akses dengan mudah oleh masyarakat ketika ingin mengetahui proses dan persyaratan suatu jenis layanan yang diinginkan oleh masyarakat.. Organisasi pemerintah yang berbasis kepada Teknologi Informasi menjadi hal yang sangat penting dalam abad ke dua puluh satu di era milineum ketiga ini. Teknologi Informasi adalah suatu teknologi yang digunakan untuk mengolah data, termasuk memproses, mendapatkan, menyusun, menyimpan, memanipulasi data dalam berbagai cara untuk menghasilkan informasi yang berkualitas.

Sejalan dengan itu, peran dan fungsi pemerintah terkait dalam kerangka mensosialisasikan peraturan-peraturan terkait dengan pelayanan publik yang telah ditetapkan serta memberikan informasi kepada masyarakat secara transparan dan cepat mutlak diperlukan. Salah satu langkah yang harus dilakukan dalam mewujudkan hal tersebut adalah dengan membuat suatu portal website yang dapat diakses untuk berbagai jenis layanan yang dibutuhkan oleh masyarakat. Dengan adanya website, informasi, komunikasi, dan transaksi antara masyarakat dan pemerintah dapat dilakukan dilakukan melalui internet. Sehingga manfaat yang dihasilkan dalam sistem tersebut berlangsung dalam hitungan jam. Informasi dapat dapat diakses dari kantor, rumah, dan sebagainya tanpa harus hadir secara langsung. Proses pelacakan informasi melalui system ini merupakan satu cara yang dapat dilakukan untuk meningkatkan kualitas pelayanan publik.

Pengadaan berbagai arsip informasi pelayanan Informasi menjadi kebutuhan mutlak bagi setiap organisasi, baik organisasi pemerintah maupun swasta. Keseluruhan kegiatan organisasi pada dasarnya membutuhkan informasi. Oleh karena itu, informasi menjadi bagian yang sangat penting untuk mendukung proses kerja administrasi 
dan pelaksanaan fungsi-fungsi manajemen dari birokrasi didalam menghadapi perubahan situasi dan kondisi yang berkembang dengan cepat. Salah satu sumber informasi penting yang dapat menunjang proses kegiatan administrasi maupun birokrasi adalah arsip Sebagai rekaman informasi dari selunuh aktivitas organisasi, arsip berfungsi sebagai pusat ingatan, alat bantu pengambilan keputusan, bukti eksistensi organisasi dan untuk kepentingan organisai yang lain. Oranisasi akan selalu membutuhkan bantuan data dan informasi untuk menyelesaikan pekerjaan dan mengefektifkan manajemennya untuk dapat mencapai tujuan-tujuan dengan baik. Pengelolaan arsip secara baik yang dapat menunjung kegiatan administrasi agar lebih lancar seringkali diabaikan dengan berbagai macam alasan. Berbagai kendala seperti kurangnya tenaga arsiparis maupun terbatasnya sarana dan prasarana selalu menjadi alasan buruknya pengelolaan arsip di hampir sebagian besar instansi pemerintah maupun swasta. Kondisi semacam itu diperparah dengan image yang selalu menempatkan bidang kearsipan sebagai "bidang pinggiran" diantara aktivitas-aktivitas kerja lainnya. Problema-problema tersebut tentu sangat memprihatinkan, karena muaranya adalah pada citra yang tidak baik pada bidang kearsipan. Padahal bidang inilah yang paling vital dalam kerangka kerja suatu administrasi.

Tertib administrasi yang diharapkan hanya akan menjadi "omong kosong" apabila tidak dimulai dari tertib kearsipannya Fungsi arsip aktif harus dapat memberi dampak positif bagi keterbukaan informasi pada pelayanan publik seiring dengan penciptaan aparatur yang bersih dan berwibawa. Sudah selayaknya arsip organisasi publik memandang bahwa kearsipan mempunyai peranan penting tidak saja dalam pelayanan interen dilingkungan instansi pemerintah tetapi juga dituntut peran aktif dalam layanan publik.

Berita terbaru tentang pelayanan Perkembangan Ilmu Pengetahuan dan Teknologi serta tuntutan modernitas masyarakat yang kian hari semakin berkembang harus mampu diimbangi oleh pemerintah dalam memberikan pelayanan kepada masyarakat yang menghendaki adanya transparansi. Tuntutan yang sering disuarakan oleh masyarakat yaitu transparansi informasi terhadap kebijakan-kebijakan, atauran-aturan terkait langsung dengan jenis-jenis layanan yang dilaksanakan pemerintah baik pusat maupun daerah. Hak memperoleh informasi merupakan hak asasi manusia dan keterbukaan informasi publik menupakan salah satu ciri penting negara demokratis.

Keterbukaan informasi publik merupakan sarana dalam mengoptimalkan pengawasan publik terhadap penyelenggaraan negara dan badan publik lainnya dan segala sesuatu yang berakibat pada kepentingan publik. Untuk itu dalam rangka pengimplementasian Undangundang No. 14 Tahun 2008 tentang Keterbukaan Informasi Publik, sosialisasi undang-undang ini. Diharapkan selunuh jajaran yang ada di lingkungan lembaga Pemerintah yang melakukan pelayanan publik, memahami dan mempersiapkan segala sesuatu yang berkaitan dengan pelaksanaan pelayanan. Kegiatan sosialisasi merupakan langkah penting yang diambil pemerintah agar supaya dapat memberikan maupun menyediakan informasi kepada publik dengan cepat, tepat waktu, berbiaya ringan dan dengan cara yang sederhana. Pelayanan publik dalam masyarakat dan keterbukaan informasi publik tidak dapat dipisahkan. Negara berkewajiban melayani setiap warga negara untuk memenuhi hak dan kebutuhan dasamya dalam kerangka pelayanan publik.

Membangun kepercayaan masyarakat atas pelayanan publik yang dilakukan penyelenggara pelayanan publik merupakan kegiatan yang harus dilakukan seiring dengan harapan dan tuntutan selunuh warga negara dan penduduk tentang peningkatan pelayanan publik, sebagai upaya untuk mempertegas hak dan kewajiban setiap warga negara dan penduduk serta terwujudnya tanggung jawab negara dan korporasi dalam penyelenggaraan pelayanan publik, sebagai upaya untuk meningkatkan kualitas dan menjamin penyediaan pelayanan publik sesuai dengan asasasas umum pemerintahan dan korporasi yang baik serta untuk memberi perlindungan bagi setiap warga negara dan penduduk dari penyalahgunaan 
wewenang di dalam penyelenggaraan pelayanan publik yang harus dibarengi dengan keterbukaan informasi kepada publik.

Pelayanan publik merupakan kegiatan atau rangkaian kegiatan dalam rangka pemenuhan kebutuhan pelayanan sesuai dengan UndangUndang No 25 Tahun 2009 bagi setiap warga negara dan penduduk atas barang, jasa, dan/atau pelayanan administratif yang disediakan oleh penyelenggara pelayanan publik, dan keterbukaan informasi publik diatur dalam Undang-Undang No 14 Tahun 2008. Pelayanan publik yang tidak dibarengi dengan keterbukaan informasi publik justru akan menjauhkan harapan masyarakat terhadap kualitas pelayanan itu sendiri.

Akses ke berbagai aplikasi Terwujudnya pelayanan prima kepada masyarakat dalam arti pelayanan yang cepat, tepat, adil dan akuntabel, merupakan harapan bagi setiap/lembaga/organisasi pelayanan publik. Oleh itu, perlu melakukan penyempumaan sistem pelayanan publik yang menyangkut perbaikan metoda dan prosedur pelayanan publik. Salah satu upaya untuk meninkatkan hal tersebut yaitu dengan melakukan Penerapan dan pengembangan Teknologi Informasi dan Komunikasi merupakan suatu langkah strategis di dalam upaya meningkatkan akses dan mutu layanan kepada masyarakat.

Teknologi Informasi dan Komunikasi sebagai sarana yang dikembangkankan harus menuju terwujudnya sistem terpadu yang dapat membangun konektivitas antar komponen yang ada sehingga menjadi lebih dinamis dan mudah diakses oleh masyarakat. Dalam rangka menghadapi era globalisasi peranan Teknologi Informasi dan Komunikasi menjadi semakin penting digunakan untuk mengungkapkan data dan fakta menjadi sebuah informasi yang sangat berharga baik terhadap pemeberi layanan maupun penerima layanan. Dengan demikian Teknologi Informasi dan Komunikasi pada hakikatnya adalah alat untuk mengakses informasi. Pembanguna pelayanan publik tidak hanya menghadapi perubahan substansi data dan fakta, lebih jauh ditantang untuk menemukan bentuk pendekatan, strategi dan metode pelayan yang mampu menjawab tantangan kebutuhan bangsa pada era globalisasi dan keterbukaan informasi sehingga diperlukan suatu kiat yang mempunyai karakter sesuai perkembangan masyarakat itu sendiri.

Pemanfaatan Teknologi Informasi dan Komunikasi menupakan salah satu solusi tepat bagi pemecahan masalah layanan publik di Indonesia. Setidaknya pemanfaatan Teknologi Informasi dan Komunkasi dalam layanan publik di Indonesia, akan dapat mengatasi permasalaan- permasalahan sebagai berikut:

1) Masalah geografis, waktu dan sosial ekonomis Indonesia. Negara Republik Indonesia merupakan Negara kepulauan, daerah tropis dan pegunungan hal ini akan mempengaruhi terhadap pengembangan infrastruktur layanan publik sehingga dapat menyebabkan distribusi informasi yang tidak merata.

2) Mengurangi ketertinggalan dalam pemanfaatan TIK dalam layanan publik dibandingkan dengan negara berkembang dan negara maju lainnya.

3) Akselerasi pemerataan kesempatan layanan dan peningkatan mutu layanan yang sulit diatasi dengan cara-cara konvensional.

4) Peningkatan kualitas sumber daya manusia melalui pengembangan dan pendayagunaan TIK.

5) TIK akan membantu kinerja layanan publik secara terpadu sehingga akan terwujud manajemen yang efektif dan efisien, transparan dan akuntabel. Ketersediaan informasi bagi masyarakat dalam menggunakan website.

Di era informasi sekarang ini, penubahan dapat terjadi dalam waktu sangat cepat. Informasi menjadi sesuatu yang sangat penting. Tanpa informasi, berupa data, informasi atau pengetahuan dan sebagainya sesuai dengan kebutuhan masingmasing, maka pengguna informasi akan kesulitan untuk menentukan keputusan yang tepat. Tidak ada seorang pun yang tidak membutuhkan informasi. Kebutuhan informasi seseorang sangat berbedabedasesuai dengan kebutuhan yang diinginkan. Hartono (2000: 692) menyatakan bahwa : 
"Informasi dapat didefinisikan sebagai hasil pengolahan data dalam suatu bentuk yang lebih berarti bagi penerimanya yang menggambarkan suatu kejadian (events) yang nyata (fact) yang digunakan untuk pengambilan keputusan" Menunut Belkin (1978: 55-85) Kebutuhan informasi terjadi karena keadaan tidak menentu yang timbul akibat terjadinya kesenjangan (gap) dalam diri manusia antara pengetahuan yang dimiliki dengan yang dibutuhkannya. Selanjutnya Chowdhury dalam Ishak (1999: 92) menyatakan sifatsifat kebutuhan informasi antara lain sebagai berikut: 1. Mempunyai konsep yang relatif. 2. Berubah pada periode tertentu. 3. Berbeda antara satu orang dengan orang lain. 4. Dipenganuhi oleh lingkungan. 5. Sulit diukur secara kuantitas. 6. Sulit diekspresikan. 7. Seringkali berubah setelah seseorang menerima informasi lain.

Mengacu pada pendapat tersebut, maka pelayanan dapat dikatakan berkualitas apabila informasi yang diberikan oleh lembaga pemerintah kepada masyarakat terhadap berbagai jenis layanan yang diinginkan oleh masyarakat merupakan informasi yang dapat dimengerti dan percaya serta mudah diakses oleh masyarakat pengguna jasa layanan. Tidak dapat dipungkiri bahwa dalam proses pelayanan yang dilakukan oleh berbagai instansi pemerintah yang memberikan layanan kepada masyarakat tidak jarang terdengar banyaknya keluhan-keluhan dari masyaraakat tentang sulitnya untuk memperoleh informasi yang akurat terkait dengan persyaratan suatu layanan. Misalnya; proses kepemilikan IMB, SITU, dan lain-lainnya. Dengan demikian maka dalam rangka meningkatkan kualitas pelayanan, keterbukaan informasi kepada publik sangat memegang peranan yang tidak bisa diabaikan oleh organisasi dalam memberikan pelayanan kepada masyarakat.

\section{PENUTUP.}

Aksessibilitas informasi dalam pelayanan publik merupakan merupakan cara yang harus didorong keberadaannya oleh lembaga pemerintah yang melaksanakan tugas pemberian pelayanan kepada masyarakat. Dimensi-dimensi dari aksessibilitas informasi perlu dilaksanakan secara proporsional dan propesional di berbagai jenis pelayanan dalam upaya untuk memberikan jaminan kepada masyarakat sebagai keterbukaan informasi publik yang merupakan salah satu ciri penting Negara demokrasi. Selanjutnya keterbukaan informasi public merupakan sarana dalam mengoptimalkan pengawasan public terhadap pelaksanaan pelayanan public.

\section{DAFTAR PUSTAKA}

Denhardt, Janet V, and Robert B. Denhardt, 2007, The New Public Service; Serving not Steering. Expanded Edition, Amron, New York:MFSharpe

Dwiyanto, Agus, 2002, Reformasi Birokrasi Publik, Yogyakarta Pusat Media.

Hartono, Jogiyanto, 2000, Pengendalian computer: Dasar-dasar Ilmu Komputer, Program, Sistem Informasi dan intelegensi buatan, edisi ke-3 cetakan ke2, Andi Yogyakarta.

Kartajaya, 2002, Perkembangan Teknologi Informasi di Indonesia, Jakarta

Thoha, Miftah, 1995, Deregulasi dan Debirokratisasi dan Upaya Peningkatan Mutu Pelayanan Masyarakat dalam Pembangunan Administrasi Indonesia, LP3ES, Jakarta

Sinambela, Lijan Poltak, 2008, Reformasi Pelayanan Publik, Kebijakan dan Implementasi, Jakarta. Raja Grafindo Pustaka.

Sulistyo-Basuki, 2003 Manajemen Arsip Dinamis,

Pengantar Memahami dan mengelola Informasi dan Dokumen, Jakarta: Gramedia

UU No. 25 Tahun 2009 tentang Pelayanan Publik. UU No 14 Tahun 2008 tentang Keterbukaan informasi. 